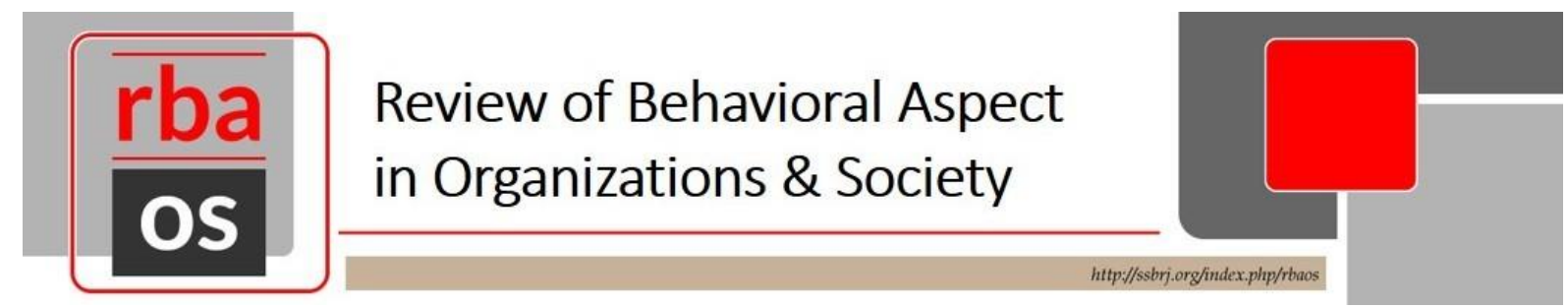

\title{
CULTURAL OPENNESS AS FUNDAMENTAL IN ERA INDUSTRIAL REVOLUTION 4.0
}

\author{
Mulyaningsih, Universitas Garut, Indonesia
}

\begin{abstract}
The tough competition in facing the Asian Future Shock of the 21st century and the replacement of human resources with robots in the 4.0 industry revolution have an impact on the human resource and economic sectors of various countries including Indonesia. The existence of a booster of cultural openness is a strategy for the development of companies that have domain expertise with a combination of local expertise. Characteristic of organizational culture sharing as a model of cultural openness rooted from local wisdom in Indonesia able to face challenge of Indonesia in managing industry process even regionally and internationally. Cultural openness in the form of the concept of transformation of the cultural characteristics of sharing organizations in the field of economy, mutual harmony and mutual cooperation, establishing relationships with safeguards and other business actors, mutual loyal and enduring, loyal to each other with the amount of labor of low educated groups and abundant raw materials relationships between subcontractors, loyalty to each other in accordance with their duties, mutual loyalty and high spirits to provide quality service, increase production capacity and seek production process resources. Indonesia has been proven able to overcome the economic crisis of 1997 is saved through SMEs with a makloon system. The methodology in the Policy Research study is a research process undertaken or an analysis of the underlying social problems with the study of literature theory, so that its findings can be recommended to decision makers to act practically in solving problems. MSMEs with integrated macro system can be integrated in the digital information era as a global conceptualizing with policy concept based on cultural openness, domain expertise, local expertise, widespread and comprehensive IT-based in Indonesia.
\end{abstract} Keywords: sharing, maklon, cultural openness. 


\section{Preface}

Indonesia's efforts to improve the capability and competence of human resources (HR) in relation to resilience in the face of the year 2020 are to build the characteristics of organizational culture values that will affect the way work and behave based on Pancasila and local wisdom (Sundanese); such as "sareundeuk saigel sabobot sapihanean, silih asah silih asuh silih sifter, simbeuh" or sharing (Mulyaningsih, 2015)

Cultural openness is a strategy for developing a company by combining domain expertise and local expertise. Characteristic sharing organizational culture as a model of cultural openness is able to face the challenges of process management industry 4.0, both regional and international.

Reconstruction of values in the cultural characteristics of local wisdom is a view of life, science, and life strategy that are done to overcome various problems of need fulfillment. A cultural transformation is a hereditary cultural heritage that contains the authority and responsibility of the government and local communities in managing natural resources based on mutual cooperation and kinship as a form of local wisdom in the sectors, politics, economy, social, culture and education (Mulyaningsih, 2017).

The above conditions can be used as a tool or a transitional bridge in combining domain expertise and local wisdom to improve competence and competitiveness of Indonesian SMEs. Here is the position of SMEs in Indonesia in 1966.

Table 1. The Role of Small and Medium Enterprises on Exports in 1966

\begin{tabular}{lccc}
\hline NICs countries & $\%$ & Non NICs Countries & $\%$ \\
\hline Taiwan & 65 & Indonesia & 6.2 \\
Hongkong & 17 & Vietnam & 20 \\
Singapura & 17 & Thailand & 50 \\
& & China & 50.6 \\
\hline
\end{tabular}

Source: Kompas Information Center (2000)

Developments after the industrial revolution era resulted in the winner of the economy through various groups of investors who are able to influence the development of business including in SMEs such as: the last wave of innovation and globalization produced winners and losers. One group of winners were investors, entrepreneurs, and high-skilled laborers that congregated around fast-growing markets and the inventions (Ross, 2016:2).

According to Ross (2016:4):

"This is a challenge and an opportunity for the development of MSMEs that must be anticipated. At the time, these political and technological shifts did not seem as important to me as they now, but the changes that took place while I was growing up in West Virginia and that accelerated with the rise of the internet have made the lives we lived even just 20 years ago seem like distant history"

Conditions like this are and will happen in the economic, social, political and legal environment in Indonesia. It requires collaboration between IT and organizational culture to produce competitive human resources through cultural openness. 


\section{Theoretical Review}

The development of Indonesian SMEs is still superior to other countries in Asia Pacific. Indonesian SMEs contributed better to the total added value of gross domestic product from 10 years back.

Table 1. Major SME Statistic as of May 2005

\begin{tabular}{|c|c|c|c|c|}
\hline Country & $\begin{array}{l}\text { Size used in } \\
\text { SME definitions }\end{array}$ & $\begin{array}{l}\% \text { of total } \\
\text { employment }\end{array}$ & $\begin{array}{l}\% \text { of total } \\
\text { worker }\end{array}$ & $\begin{array}{l}\% \text { SME contribution to } \\
\text { the total added value of } \\
\text { GDP }\end{array}$ \\
\hline Malaysia & Staffing and sales & 99.2 & 65.1 & $47.3^{\mathrm{c}}$ \\
\hline Japan & $\begin{array}{l}\text { Employment and } \\
\text { assets }\end{array}$ & 99.7 & 70.2 & $55.3^{\mathrm{a}}$ \\
\hline Taiwan & $\begin{array}{l}\text { Personnel, sales } \\
\text { and capital }\end{array}$ & 97.8 & 77.2 & n.a \\
\hline Korea & Staffing and sales & 99.8 & 86.7 & $50.0^{c}$ \\
\hline Thailand & $\begin{array}{l}\text { Personnel and } \\
\text { fixed assets }\end{array}$ & 99.6 & 69.0 & $38.9^{\mathrm{a}}$ \\
\hline Singapore & $\begin{array}{l}\text { Personnel and } \\
\text { fixed assets }\end{array}$ & 91.5 & 51.8 & $34.7^{\mathrm{c}}$ \\
\hline Germany & $\begin{array}{l}\text { Personnel and } \\
\text { asset sales }\end{array}$ & 99.7 & 79.0 & $57.0^{\mathrm{b}}$ \\
\hline Indonesia & $\begin{array}{l}\text { Employment, sales } \\
\text { and assets }\end{array}$ & 99.9 & 99.6 & $57.0^{\mathrm{a}}$ \\
\hline China & $\begin{array}{l}\text { Employment and } \\
\text { assets }\end{array}$ & 99.0 & 69.7 & $60.0^{c}$ \\
\hline Philippines & Staffing and sales & 99.6 & 69.1 & $32.0^{\mathrm{c}}$ \\
\hline
\end{tabular}

Note: GDP ${ }^{\mathrm{a},} \mathrm{GNP}^{\mathrm{b}}$, nilai tambah total (Nelson Oly Ndubisi: 2008, 25)

Source:

Malaysia : Census 2005

Japan : Annual report JASME 2004-2005, JASME :(http://www.jasme.go.jp)

: APEC-SME Profile (http://www.actetsme.org)

: A Framework for the Development of Malaysia (BNM 2003)

Taiwan : White Paper on SMEs in Taiwan 2015, SMEA (http://www.moeasmea.gov.tw)

Korea $\quad: \quad$ Korean SMEs (2002), SMBA (http://www.smba.go.kr)

Thailand : White Paper on SMEs in in Thailand 2002, OSMEP (http://www.sme.go.th)

Singapore : APEC - SME Profile (http://www.actetsme.org)

Germany : SMEs in Germany - Facts and Figures 2004, and Mittelstand Definition and Key Figures (2003), Ifm Bonn (http://www.ifmbonn.org)

: A Compreherensive Framework for the Development of SMEs in Malaysia (BNM 2003)

Indonesia : APEC - SME Profile (http://www.actetsme.org)

China : APEC - SME Profile (http://www.actetsme.org)

Philippines : National SME Development Agenda (NSO - 2000/2001), DTI (http://www.dti.gov.ph) 
: APEC-SME Profile (http://www.actetsme.org)

MSMEs in Indonesia have a large share, seen from the data as follows:

Development of Micro, Small, Medium Enterprise (MSME) data in Indonesia;

2009 number of SMEs 52,764,750 units with a share of $99.99 \% 2$

2010 the number of SMEs 54,114,821 units with a share of $100.53 \%$

2011 number of SMEs 55,206,444 units with a share of $99.99 \%$

2012 the number of MSME 56,534,592 units with a share of $99.99 \% 2$

013 number of MSME 57,895,721 units with a share of $99.99 \%$

It is estimated that the contribution of MSME Up from 2014-2016

the number of MSME more than 57.9 million units and by 2017 the number of MSMEs is estimated to grow to more than 59,000,000 units. (Source: depkop.go.id)

Based on data compiled by the Ministry of Cooperation and SMEs, Indonesia is the country with the largest SMEs in Southeast Asia (58 million businesses).

Indonesia has the Greatest SMEs in Southeast Asia. Digital Indonesia, a technology company that provides internet-based platform for SME, introduces a go online movement. This movement is fully supported by the Ministry of Cooperation and SMEs and several other institutions, such as Google, Astra Life, Veritrans, BNI and SMESCO. Secretary Ministry of Cooperation and SMEs, Agus Muharram stated that go-online SME is one of the main focuses of the Ministry of Cooperation and SMEs. He added that there are currently three most influential subcultures to the market, namely youth, women, and netizens. All three of these powers are familiar with the online world, so SMEs who do not go online will lose the market (Agus Muharram, Secretary Ministry of Cooperation and SMEs, (24/8/2016).

The contribution of micro, small and medium enterprises to gross domestic product increased from $57.84 \%$ to $60.34 \%$ in the last five years. Labor absorption in this sector also increased, from $96.99 \%$ to $97.22 \%$ in the same period. Although the contribution indicators for the formation of gross domestic product (GDP) and labor absorption rose, access of micro, small and medium enterprises (MSME) sector to global supply chain is very minimal. MSME's contribution in Indonesia to the global supply chain is only $0.8 \%$. The contribution of MSME increases (Ministry of Industry 2018). MSME's contribution in Indonesia to the global supply chain is only $0.8 \%$.

Current business conditions are inseparable from the internal and external environment of the company, either directly or indirectly. This can be seen from the Figure 1.

In addition to the environment above the LGDP-KMSME cultural supports that must be animated and organized by its entire staff are:

1. Promote the principles of good governance (transparency, accountability, efficiency, openness, and law enforcement) in every activity.

2. Guided to the system as a reference work.

3. Be honest, positive thinking, dedicated and trustworthy.

4. Always improve professionalism for the achievement of added value for LGDP KMSME. 
5. Oriented to the success of government programs.

6. Oriented to the development of Cooperation and MSME.

7. Proactive to environmental changes. The ministry of cooperation and MSME http://GGP.id/profile/sejarah.htm,2017

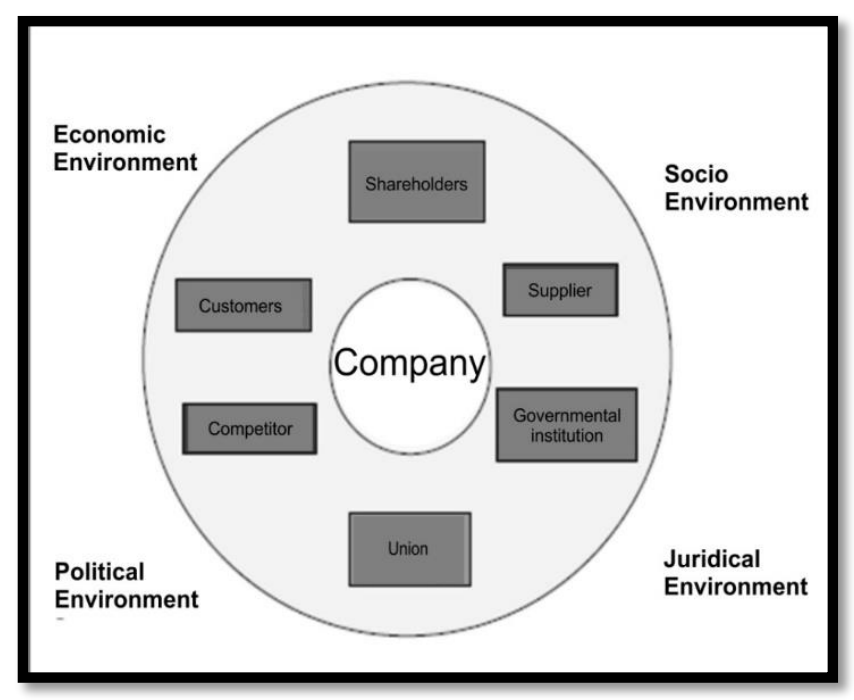

Source: Situmorang (2009)

Figure 1. Some of the links between politics and business

In economic growth with financial enhancement, the care of community values embraces various risks that threaten the life of the nation and human development, which ensures the availability of a quality workforce to deal with the 21 st century conditions as an effort to lead to increased human resource competencies to boost fundamentals of economic resilience Indonesia based on kinship and the existence of MSME environment in the life of Indonesian nation today.

The characteristics of organizational culture sharing in improving the competence of human resources MSME can be seen in the table as follows:

Table 2. Characteristics of organization culture sharing in increasing competence HR MSME

\section{Research result $\quad$ Field $\quad$ Characteristics of Sharing Culture}

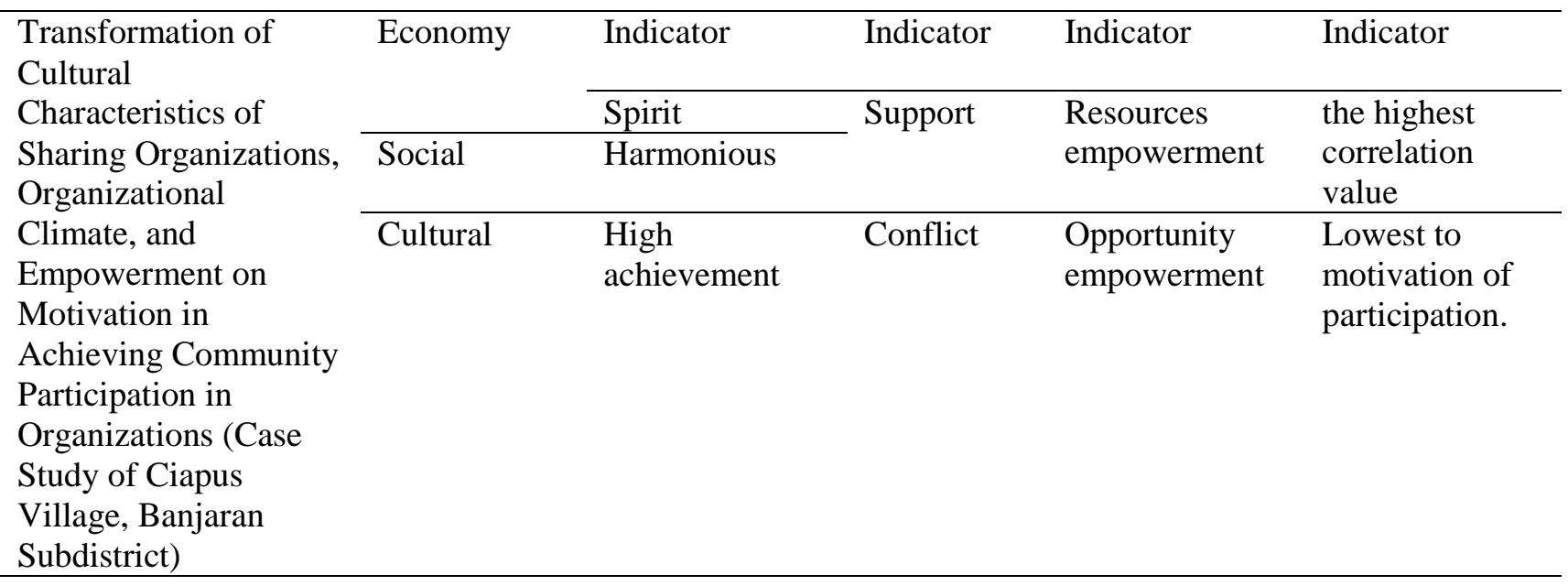




\begin{tabular}{|c|c|c|c|c|c|}
\hline $\begin{array}{l}\text { Transformation of } \\
\text { Organizational Culture } \\
\text { Planning Against } \\
\text { Educational } \\
\text { Management to } \\
\text { Achieve Effectiveness } \\
\text { of Cultural Use } \\
\text { Sharing in Education } \\
\text { Environment (Survey } \\
\text { At state junior high } \\
\text { school In West Java) }\end{array}$ & Education & $\begin{array}{l}\text { Carry out the } \\
\text { planned } \\
\text { activities }\end{array}$ & $\begin{array}{l}\text { Together in } \\
\text { planning } \\
\text { activities } \\
\text { and } \\
\text { budgets }\end{array}$ & $\begin{array}{l}\text { Harmonious to } \\
\text { account for the } \\
\text { expenditure of } \\
\text { funds }\end{array}$ & $\begin{array}{l}\text { a. Implement } \\
\text { activities that } \\
\text { have been } \\
\text { planned } \\
\text { b. Plan } \\
\text { activities and } \\
\text { budgets } \\
\text { c. Report in a } \\
\text { transparent } \\
\text { manner }\end{array}$ \\
\hline
\end{tabular}

Characteristics of "sharing" is a strategic characteristic of the organizational culture characteristics of SME Indonesia's human resources as a tool to support the implementation of development progress through measurable capabilities with an organized entrepreneurship capacity for the behavior of SME actors in the way employees work and owner behavior varies according to country and depends on the perceived businessman and the formation of a collaborative meeting between the modern paradigm, the transformational paradigm and the liberal paradigm so as to shape the "Attitudes, beliefs, assumptions and expectations shared that may not be recorded, but shaping the way people act and interact within organizations and support how things are done " (Armstrong 1995) is based on the commitment of the principle of think globally act locally (Mulyaningsih, 2015).

Shared patterns of attitudes, beliefs, assumptions and expectations that may be recorded to interact as a supportive and committed effort in action can be done as a map taken in a rich environment sharing their own knowledge and proven solutions for the completion of work in the global world corresponding to one of the cultural maps:

Many have shared their own wisdom and their tested solution for getting things done is global word, the rich trove of information and experience informs the eight-scale model that is at the heart of the book. Each of the eight scales represents one key area that managers must be aware of showing how cultures very long a spectrum from extreme to its opposite. The eight scales are:

- Communicating: low-context vs high context

- Evaluating: direct negative feedback vs indirect feedback

- Persuading: principles-first vs applications-first

- Leading: egalitarian vs hierarchical

- Deciding: consensual vs top-down

- Trusting: task-based-relationship-based

- Disagreeing: confrontational vs avoids confrontation

- Scheduling: linear-time vs flexible-time.

Hope that will be achieved if supported by qualified human resources owned by every nation with quality improvement to be a new paradigm in the future may only be answered by qualified human resources who have integrity and professional. Globalization, democratization, science and technology, environment and human rights enforcement and the issue of massive migration especially in ASIA coloring the condition of human resources of Indonesia in the future.

The development of key Asian companies in the future will be controlled by charitable trusts. Indonesia will run out of oil with a sense of regret considering the many opportunities that 
have been wasted in decades before. The level of wages in Indonesia is low due to corruption so that Indonesia becomes an expensive place to do business and the role of culture is very important. Culture is a system of sharing of symbols, beliefs, attitudes, values, expectations, and norms to behave (BoveeCourtland and Thill, 2013). While the influence of organizational culture on organizational performance in industry is very large in accordance with the results of research, as follows: Organizational culture is analyzed as the second factor relevant in the management of human resources in automotive companies Japan considering the organizational culture factor is very dominant influence in determining the behavior of employees in companies whose parents are from Japan (personal communication with Senior Production Manager at Indonesia's spare-part automotive company). The statement is theoretically supported by Neal et al. (2004:3) who said, "Organizational climate, like HRM, is thought to be important determinant of organizational effectiveness".

At automotive companies from Japan, the organizational culture factor is dominant in coloring management infrastructure. Even the automotive production system itself cannot be separated from the national culture of Japan. When the work system is applied in other country, there will be a socialization process which is certainly not easy and takes time.

Successful implementation of a multi-skill system or cooperation in Japan, when brought to Western countries where culture may be more egocentric and emphasize individual performance is initially not easy to implement and therefore requires adjustments. The same is true of Japanese companies operating in Indonesia. However, in this study, the organizational culture to be studied is not directly adopted from Japanese organizational culture, as this research is part of a multi-industry wide-scale research. The organizational culture to be studied is that it supports high performance, as Makhijani et al. (2009) that in order to drive the success of the organization's business, it is necessary to present a highperforming organizational culture or high performing culture (Susilowati, Pasaribu and Djohar, 2013).

Characteristics of "sharing" has the highest correlation value to the participation process with high achievement motivation while the characteristics of sharing organizational culture are morale, conflict climate, and empowerment opportunities have the lowest value to the form of participatory motivation. Participation activities that build the characteristics of sharing the same organizational culture the high fighting spirit of a little conflict provides an opportunity to meet the needs of power (awards) and need to continue to be built characteristics of sharing organizational culture together harmoniously supported with resources with a clear participation process of achievement for village officials, community leaders and young people in the Village Ciapus Banjaran District Bandung (Mulyaningsih, 2017) concerning the process of natural resource exploration with cooperation process based on the principle of mutual respect, mutual respect, mutual cooperation, mutual trust, mutual benefit and mutual grasp.

Cultural openness in the form of the concept of transformation characteristic cultural sharing organization in the field of economy. Indonesia has proven able to overcome the economic crisis of 1997 is saved through MSME with makloon system. Makloon is all the provision of services in the course of the process of settlement of a certain good which process of raw materials or intermediate goods or helper / helper which will be processed as or wholly provided by the service user and its ownership of finished goods are in the service provider according. 
The makloon system is a system that is run by MSME in Indonesia to date, using business sharing (capital), sharing of personnel, sharing market using philosophy of kinship and mutual cooperation so that until now even in 1997 Indonesia Economic crisis MSME is not a multi-national company, it proves that MSME can become a "primadona" (the most preferred one) in Indonesia.

\section{Methodology}

a. Policy Research The methodology in this study is to define a process of research conducted or an analysis of the basic social problems, so that its findings can be recommended to decision makers to act practically in solving problems

b. The main objectives of this research are action research on situation change, behavior, organization including work mechanism structure, work climate and institutions

c. Implementation of data processing in this research is focused on solving problems encountered in the present or actual problems.

d. Top collection techniques;

1) The results of the study and the study data were collected, compiled, explained and analyzed from the results of studies and studies already disseminated both within and outside the country

2) The scope of research in the results of organizational effectiveness, bodies, and forms of economic behavior of MSME that include the cultural values of the organization, the effectiveness and satisfaction of organizational members, the advantages, and may arise new occupations or new thinking through qualitative research departing from the view of the world (phenomena) are plural dimensional, interactive and demanding interpretations based on social experience. Considering reality as a social construct, the individual or group draws or gives meaning to a reality by reconstructing the inference of inferred conclusions from one or more specific facts or pieces of evidence, and constructs of a collapse.

3) Construct, is a shadow or thought that is specifically created for a study and / or for the purpose of constructing the theory and then modeled from several theoretical studies and from the results of previous research and literature studies, the results of the study to be used in the application of solving problems with explanations descriptively Model is defined as a reflection of a system designed to study one aspect of the system or of the system as a whole.

\section{Discussion}

a. Openness Culture as Fundamental mindset of HR In The 4.0 Era of Revolution Industry

A "sharing" culture as a tool for performance as well as developing an organizational culture that will support innovation and flexibility, as well as resources in Indonesia can be competitive with high performance with the development of an innovative organizational culture and flexibility.

Implementation of human resource management with organizational strategy improves performance and develops the characteristics of organizational culture sharing that will support the application of innovation and flexibility. In the era of intense global competition, human resources are considered as one of the most important factors playing a leading role in maintaining organizational sustainability, credibility and creation of public trust. Emphasis on human resources as valuable capital in the organization reflects more pressure on the intangible resources than the real (Kalangi, 2015). 
Developments in the industrial revolution era 4.0 will form an issue in terms of social and cultural context, put forward by Ross: and humans are adept at things that machines find difficult (such as creativity or understanding social and cultural context) 2016:182 and the necessity of certain cultural characteristics, norms in society and encouragement and government control as presented by Ross; and The geography of future markets; world leaders take notice: The $21^{\text {st }}$ century is terrible time to be a control freak. The popular recipe for creating the "next" Silicon Valley goes something like this:

- Build a big, beautiful, fully equipped and technology park;

- Mix in R\&D labs and university centers;

- Provide incentives to attract scientists, firms and users;

- Interconnect the industry though consortia and specialized supplies;

- Protect intellectual property and tech transfer; and

- Establish a fordable business environment and regulation,

Building an innovation-rich place like Silicon Valley requires specific cultural and labor-market characteristic that can contradict both a society's norms and the more controlling impulses of government leaders (Ross, 2016:186-187).

In the economic growth with financial enhancement, the care of the values embraced by the community from various risks that threaten the life of the nation and the country and human development, which ensures the availability of quality workforce to face the conditions in the 21 st century as an effort to lead the increase in human resource competence to boost fundamentals Indonesia's economic resilience based on kinship and the existence of MSME environment in the life of Indonesian nation today. These conditions can be showed as follows:

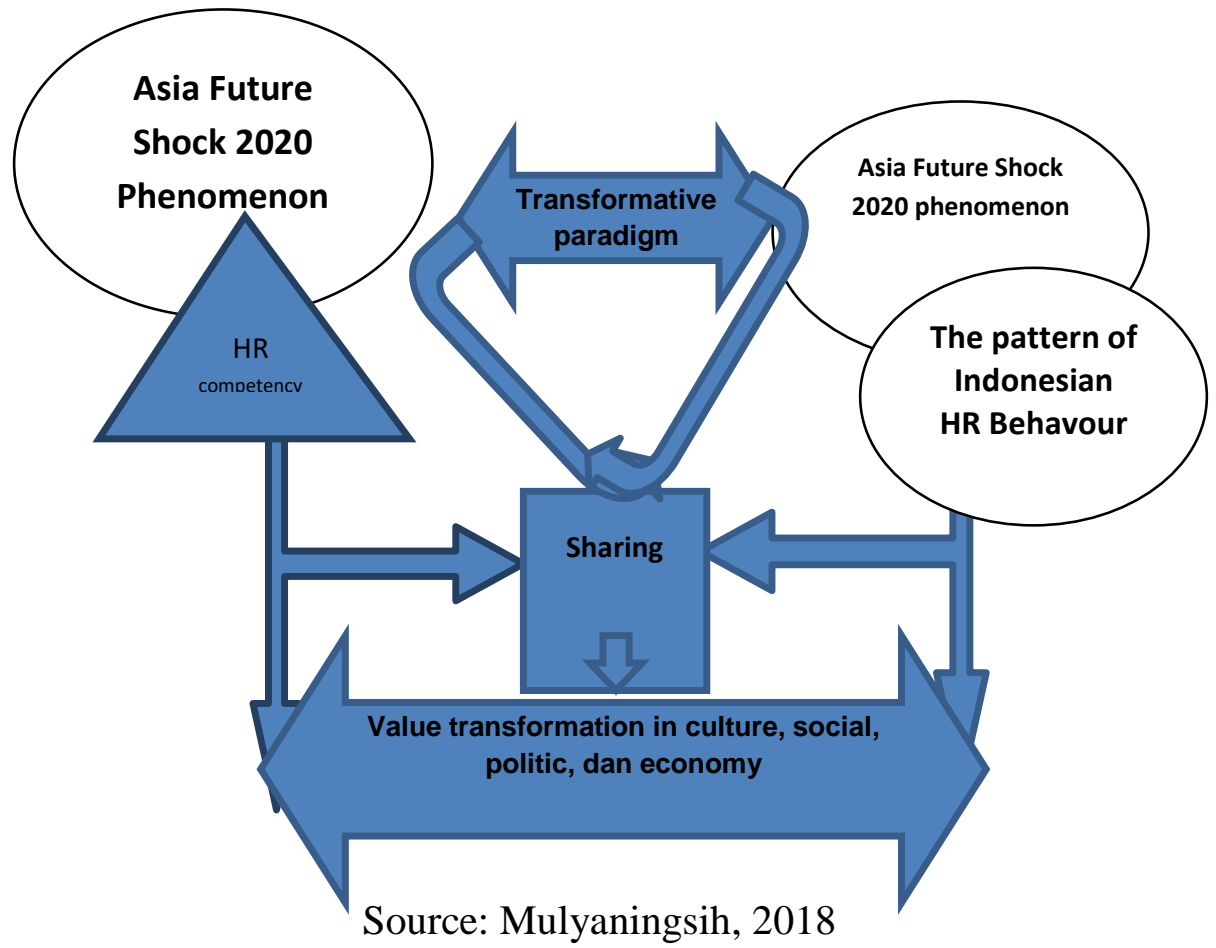

Figure 2. The transformation of sharing culture organization characteristics as a rebounding result of local wisdom value in improving Indonesia's community competence in the 21 st Century 
Cultural openness in the form of the concept of transformation characteristic cultural sharing organization in the field of economy, both harmonious and mutual cooperation, establish relationships with safeguards and other business actors, both loyal and survive, equally faithful to the large number of workers of low educated and abundant raw material relationships between subcontractors, are equally faithful to work in accordance with their duties, equally faithful and high spirits provide quality service, increase production capacity and seek production process resources in accordance with the system makloon. The Makloon Strategy is production cooperation between the brand owner and the manufacturing / service company. Makloon can be contracted or there is a label as a private label, is a way for manufacturers to take advantage of factory utility that is still not maximized by producing orders from other companies' brands.

Traditional cultural values such as family safety and relationships, respect for parents and parents and family loyalty are still supported by many young adults. However, teenage samples are also influenced by global values such as freedom, personal goals, ambitions, riches, pleasures and varied lives. Many young individualism, liberalism, and intrinsic rewards are emphasized by the results of the study as follows:

"The findings suggest that traditional culture values such as family security and relationships, honoring of parents and elders and family loyalty are still strongly supported by many young adults. However, the sample youth was also influenced by global values such as freedom, personal goals, ambition, wealth, pleasure and a varied life. Many young individualism, liberalism and intrinsic reward". (NgYinLing, Tabitha, 2015)

\section{b. IT Collaboration with Cultural Transparency as a Fundamental Human Resource Mindset In The 4.0 Era of the Revolution Industry}

The 4.0 industry revolution has built the world as a global village with openness has attracted people outside Indonesia to invest in various IT-based areas such as FreakOut in 2015; FreakOut is ambitious to diversify business, one of them by launching native ad service. Not without reason if FreakOut glance at Indonesia. In the country, although the contribution of new digital advertising expenditures grew by $4.7 \%$ and advertising spending on mobile internet was only $0.04 \%$ of total media advertising expenditure in Indonesia in 2014, but growth is expected to increase. As predicted by eMarketer in Media Buying Indonesia study published in April 2015, it was stated that digital advertising contribution will increase to $25.1 \%$, and mobile internet advertising contribution will increase to $13.7 \%$ by 2019: "Total advertising expenditure market in Indonesia in 2019 will be worth about US \$ 19.58 billion (around Rp263, 6 trillion). During the forecast period, Indonesia will have the highest growth rate of digital advertising spending and the world's highest mobile advertising, "eMarketer wrote in its report. The positive growth prediction of ad spending in the digital and mobile segment is what makes (Baziad, 2015).

The condition above proves that the flood of IT Investor is not can be dammed, this is in addition as a threat as well as opportunities for the Indonesian nation to collaborate utilizing IT with cultural openness through the great human resources and natural wealth and culture owned. In some developed countries SME trade such as Hong Kong was built on initiatives from family, government and IT cultures so Hong Kong became a more hospitable city. It is proposed that the government should facilitate joint efforts 
between the public, private and non-government sectors to make Hong Kong a more family-friendly city. Since this is a study on youth's perceptions on global values, local cultural values and parenthood, the focus group approach whit a non-probability and purposive sample, which was identified through a snowball method, was used for this qualitative study. (NgYin-Ling, Tabitha, 2015)

For that reason, the need for cultural cultivation through the study of adolescent perceptions of global values, local cultural values and parents, focus group approaches with non-probabilistic and purposive samples, identified by snowball method is particularly concerned about researchers of this culture.

It is proposed that the government should facilitate joint efforts between the public, private and non-government sectors on how to make Hong Kong a more family-friendly city. The results of this study apply stakeholder theory in understanding the importance of managing good relationships among stakeholders useful in building network capital for SMEs carrying out business responsibilities that emphasize the calculating, economic, rational and professional factors. According to Ginting (2016):

"This study applies the stakeholder theory in understanding the importance of managing good relationships between stakeholder which are useful in establishing network capital for SMEs in practicing business responsibility that puts emphasis on calculative, economic, rational and professional factors".

In the context of MSME Indonesia's problems, SME is not yet fully concerned about business responsibility, since business responsibilities are mostly active in local / national markets. However, SMEs that start expanding their markets through exports are required to meet the demands of key stakeholders such as buyers, governments, suppliers, agents and customers.

In general, the demands of stakeholders are as follows: internationalization, product standardization, most SME financing that is not feasible to offer credit, quality standards, innovation, human capacity building and various rules imposed on products to enter the world market (Wengel \& Rodriguez, 2006; Tambunan, 2007; OECED, 2009). In accordance with In the Indonesia context, according to (Wengel \& Rodriguez, 2006; Tambunan (2007) and OECED, 2009:

"SMEs have not yet fully concerned themselves about business responsibility, because business responsibility is mostly active in the local/national markets. However, SMEs which are beginning to expand their markets through exports are required to meet the demand of primary stakeholder such as buyers, government, suppliers, agents and customers. In general, the demands of stakeholders are as follows: internationalization, standardization of product, most of the SMEs financing being not feasible to offer credit, quality standards, innovation, an increase in capacity of human resources as well as the various rules imposed on the products to enter the world market."

"This model explain that it is possible to develop marketable height quality products, ensure a comfortable working environment and reduce negative environmental impacts if manger implement social responsibility and manages to attain good relationships with multi-stakeholders. In other word, managing external stakeholder means "environmentally friendly" SMEs business give positive impacts on communities, customers, government and employees. This model fulfils the 
requirement of SMEs in Indonesia which are currently facing the phenomenon of "growing interest in entering the international/global market" (Wismiarsi et.al.,2009; Ginting, 2016).

The model explains that it is possible to develop marketable high-quality products, ensure a comfortable working environment and reduce negative environmental impacts if the manger carries out social responsibility and manages to achieve good relationships with multi-stakeholders. In other words, managing external stakeholders means that an "environmentally friendly" SME business has a positive impact on society, customers, governments and employees. This model meets the SME requirements in Indonesia that currently face the phenomenon of "increasing interest in entering international / global markets" (Wismiarsi et.al. 2009; Ginting, 2016).

The full investor position is central, and the density and stakeholders faced by the owners make important considerations ensuring that the relationships built can provide the economic, rational and investment benefits of network resources owned by stakeholders as partners of business activities. Includes Relationships with suppliers, bureaucracy and internationally. In accordance with the model;

"This model could be used to explain that owners/managers internally managing the relationships whit stakeholders in implementing business responsibility would have developed and marketed high quality products, ensured a comfortable working environment, and reduced negative environmental impacts. Managing relationships with external stakeholders in the context of business responsibility involves a company to deliver products that satisfy consumers and employ disabled people, build good relationships whit suppliers on the basis of a win-win solution, collaborate with agencies and universities in order to encourage innovations and build networking with the government in order to overcome limitations in terms of regulation, bureaucracy, and information of international market opportunities." (Ginting, 2016).

This model can be used to explain that owners / managers internally manage relationships with stakeholders in carrying out business responsibilities will develop and market high quality products, ensure a comfortable working environment, and reduce negative environmental impacts. Meanwhile, the aspects of centrality and density as well as the multiple stakeholders faced by owners/managers of SMEs should be important considerations in ensuring the relationships built could provide economic, rational and investment benefits of the network resources owned by stakeholders as a partner of the business activities.

Meanwhile, the centrality and density aspect as well as the various stakeholders faced by SME owners / managers should be an important consideration in ensuring co-workers, investors and relationships with government. Managing relationships with external stakeholders within the context of business responsibility involves companies to produce products that satisfy consumers and employ people with disabilities, build good relationships with suppliers based on win-win solutions, collaborate with institutions and universities to drive innovation and build networks with governments to address limitations in regulation, bureaucracy, and information on international market opportunities.

Thus the model will be built to collaborate the characteristics of sharing organization culture internationally for MSME in Indonesia so that in addition to remaining a king in his own 
country and even able to compete internationally rely on local strength, the openness of ITbased culture is as follows:

Collaborative Model Characteristics of organization sharing organization in MSME for stylish and competitive IT based on the following model:

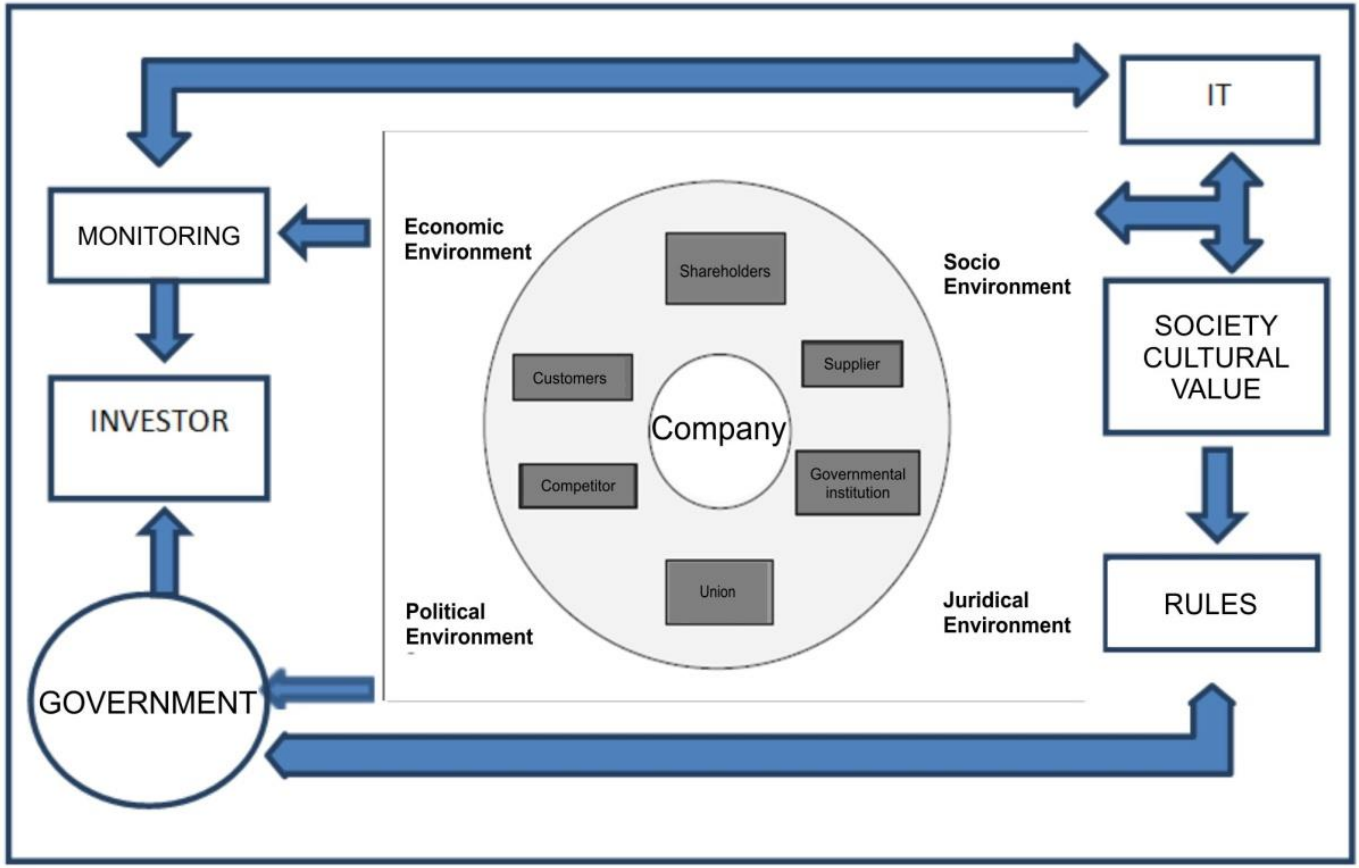

Figure 3. Model 1: IT collaboration with cultural transparency as a fundamental human resource mindset in the 4.0 era of the revolution industry

Collaborative Model Characteristics of sharing organization culture in MSME to be competitive and IT-based will involve:

1) The wealth of human resources with a lot of low education

2) The natural wealth that exists

3) Local culture

4) Central Role

5) The role of government

6) IT-based Business Environment In a survey conducted by InMobi Insights titled "Marketer and Publisher Perceptions: Native Advertising on Mobile"

In an IT-based business environment it is necessary to cultivate in addition to outside investors as well as cultural openness by combining a large number of low-education workers as domains of shareholders, suppliers, customers, competitors, unions and government agencies with the characteristics of sharing culture

\begin{tabular}{|l|l|l|l|l|}
\hline \multicolumn{1}{|c|}{ Economy } & Indicator & Indicator & Indicator & Indicator \\
\cline { 2 - 3 } & $\begin{array}{l}\text { Fighting } \\
\text { spirit }\end{array}$ & Support & $\begin{array}{l}\text { Resources } \\
\text { empowerment }\end{array}$ & $\begin{array}{l}\text { High correlation } \\
\text { value }\end{array}$ \\
\hline Social & Harmonious & Conflict & $\begin{array}{l}\text { Opportunity } \\
\text { empowerment }\end{array}$ & $\begin{array}{l}\text { Low motivation in } \\
\text { participation }\end{array}$ \\
\hline Cultural & $\begin{array}{l}\text { High } \\
\text { achievement }\end{array}$ & & \multicolumn{2}{|c|}{} \\
\hline
\end{tabular}


Must be built through government oversight, legal arrangements, IT-based with informed through internet media; InMobi Insights titled "Marketer and Publisher Perceptions: Native Advertising on Mobile", E comers etc. for the business environment of MSME Indonesia's corporate makloon system. Thus Cultural openness with low quality human resource domain, natural resources can be exploited without having to sacrifice noble values of the nation to bolster the economy of Indonesia through the collaboration of Human Resource Competence in the era of industry revolution 4.0 because the business environment is supervised by bureaucracy, regulations and IT centers exist under the government as a form of human resource oversight, Cyber Crime, and the monopoly of human resources, natural resources, and culture.

\section{Closing}

Openness of culture as fundamental in 4.0 era of the industrial revolution in Indonesia with the makloon system can be encountered through collaborating the IT-based business environment, the culture of "sharing" in the economic environment; morale, support, empowerment resources, highest correlation value, social environment; harmonious and culture; high achievements, conflicts, empowerment opportunities, lowest motivation for participation are implemented against shareholders, suppliers, customers, competitors, unions and government agencies including overseas investors overseen by government.

\section{References}

Baziad, M. (October 14, 2015). FreakOut Masuk Pasar Indonesia. Retrieved from http:// https://www.digitalnewsasia.com/business/freakout-masuk-pasar-indonesia.

Bovee, C. L., \& Thill, J. V. (2013). Business communication. Prentice Hall.

Ginting, G. (2016). Modelling business responsibility of SMEs: a study based on the stakeholder approach. Pertanika Journal of Social Sciences \& Humanities, 24(3).

Kalangi, R. (2015). Development of human resources and the performance of the state civil apparatus in the Sangihe Islands Regency of North Sulawesi Province. Jurnal LPPM Bidang EkoSosBudKum, 2(1), 1-18 (translated from Indonesian: Pengembangan sumber daya manusia dan kinerja aparat sipil negara di Kabupaten Kepulauan Sangihe Provinsi Sulawesi Utara. Jurnal LPPM Bidang EkoSosBudKum, 2(1), 1-18).

Ministry of Industry (2018). The contribution of MSME increases. Retrieved from http:// http://www.kemenperin.go.id/artikel/\%2014200/Kontribusi-MSME-Naik.

Mulyaningsih, (2015). Characteristics of organizational culture reconstruction in Indonesia in increase competence and human resources (Preparation to face future shock asia 2020). Proceeding Joint Seminar KORPRI Kopertis Region IV Tsukuba University and Meijo University. pp. 31-37.

Mulyaningsih. (2017). The influence of educational policy implementation and transformation of organizational culture on school management to realize the effectiveness of the use of cultural sharing in the educational environment (survey of Public Middle Schools in West Java. Journal of Seretary \& Business Administration, 57-69. (translated from Indonesian: Pengaruh implementasi kebijakan pendidikan dan transformasi budaya organisasi terhadap manajemen sekolah untuk mewujudkan efektivitas penggunaan budaya sharing di lingkungan pendidikan (survei pada SMP Negeri di Jawa Barat). Journal of secretary \& business administration, 57-69).

Mulyaningsih. (2018). The transformation of sharing culture organization characteristics as a rebounding result of local wisdom value in improving Indonesia's community competence in the 21st century. Journal of business and Finance in Emerging Markets, $1(1), 79-89$. 
NgYin-ling, Tabitha. (2015). Impact of global and chinese cultural values on young people's perceptions of parenthood Hong Kong, China. Pertanika Journal of Social Sciences \& Humanities, 23(4), 867-884.

Ross, A. (2016). The industries of the future. London-New York-Sydney-Toronto-New Delhi: Simon and Schuster.

Situmorang, J.R. (2009). Some of the links between politics and business. Jurnal Administrasi Bisnis, 5(2), 146-159. (translated from Indonesian: Beberapa Keterkaitan antara Politik dan Bisnis. Jurnal Administrasi Bisnis, 5(2), 146-159).

Susilowati, Y., Hutagaol, P., Pasaribu, B., \& Djohar, S. (2013). Effect of aspects of human resource management on improving organizational performance in the automotive industry in Indonesia. Journal Manajemen Teknologi, 12(1), 21-39. (translated from Indonesian: Pengaruh aspek pengelolaan sumber daya manusia terhadap peningkatan kinerja organisasi di industri otomotif di Indonesia. Journal Manajemen Teknologi, 12(1), 21-39). 
